\title{
Land elevation and slope exposition impacts on rubber wood production volume under agroforestry system
}

\author{
Samsul Bakri ${ }^{1,2}$, Christine Wulandari ${ }^{1,2^{*}}$, Rusita Jamal ${ }^{3}$, and Ghina Zhafira ${ }^{4}$ \\ ${ }^{1}$ Graduate School of Forestry Science, College of Agriculture \\ ${ }^{2}$ Graduate School of Environmental Science, College of Interdisciplinary \\ ${ }^{3}$ Department of Forestry, College of Agriculture \\ ${ }^{4}$ Study Program of Forestry, College of Agriculture \\ Universtitas Lampung, Jalan Sumanteri Brojonegaro \#1, Bandar Lampung-Indonesia 35145
}

\begin{abstract}
As the senile phase due and causes depeleting latex productivity, the rubberwood stands can still be claimed as carbon sequestration under the $\mathrm{REDD}^{+}$Scheme. This is also to maintain vegetation cover in protected forests, beside for fostering social forestry $(\mathrm{HKm})$ sustainability as well. Nowadays the role of genetic and environment factors on latex production have widely revealed by some researchers, but lack on wood production especially for the effect of land elevation and slope exposition against solar beam radiation so need to research. Ordinary Least Square employed at 95\% significant level, the respond variable was the volume wood production per tree, whereas the predictor were land elevation in an-100 $\mathrm{m}$ above sea level, land slope expositions that were decomposed into 4 categories with the reference of the compass direction in between $337^{0} .30^{\prime}$ to $225.5^{\circ}$ follow needle clock's direction while the three other directions were the westward, southwest ward, and northwest ward. Air humidity and temperature also incorporated to control model error. Data collected by surveying to 75 parcels at HKm area Mangga Joyo located in Way Kanan Regency. Parameter optimization used Minitab 16. The result suggest that wood volume average: (1) increase significantly by $0.02205 \mathrm{~m}^{3}$ for every $100 \mathrm{~m}$ higher elevation, but (2) decrease significantly by $0.21532 \mathrm{~m}^{3}$ which for westward land exposition compare to the eastward one.
\end{abstract}

\section{Introduction}

\subsection{Research background}

Growth and development of plant are controlled by both genetic and environment factors so does the rubber tree (Hevea brasiliensis). Because of widely used in some industry inputs, the research on effect of booth factors have been conducted exhaustively to increase the latex productivity and quality [1 - 4], and so did [5] reported their research on the roles of genetic

\footnotetext{
* Corresponding Author: christine.wulandari@fp.unila.ac.id
} 
factor on the latex productivity of some types of clonal resulted from the previous breeding. As for the extensive of research environmental effect on rubber growth and latex productivity can be referenced the work reported by [6] especially for climate factors (air temperature and rainfall) in relation to land suitability, [7] for soil fertility and management etc. None of these research reveals the roles of the genetic and environmental factors on rubber wood production but on latex productivity.

Having exhaustively endeavour for searching publication about the effect the two factors on rubber wood product, we almost failed to find it. However [8], fortunately, has reported the role of cropping management of leave pruning on rubber stem diameter development. Additionally [9] also have contributed the effect of air humidity and air temperature on stem performance. But both research were employed merely on the rubber seed nursery conditions, that may be give very different effect in case on applying at opened field area with various of environment factors including the terrain of land such as elevation and slope exposition. In relation to this matter, [10] reported that for every moved up a-100 m across the landscape there would be improvement in bean quality indices of a-1000 weight in one hand but worsen the indices of float bean in water soaking in the other hand. Further [10] also reported that the west ward slopes exposition had no effect significantly on the first indices but on the second indices respectively. We are interesting in revealing the effect of the two terrain land attributes on rubber wood volume production. The two land attributes will determine on resource allocation in agroforestry system during the period of cultivation and latex harvesting as well as in logging wood when the replanting phase will be due. The relationship model of rubber wood production and two variables are also very important for some programs of Indonesian Government to reforestation especially for REDD ${ }^{+}$Scheme under Paris Agreement regime as [11] and [12].

Based on the lesson explained bay [11] it is implied that by applying rubber agroforestry system in reforestation programs under Paris Agreement commitment (REDD ${ }^{+}$sheme), Indonesia will bring some benefits, i.e it will reaffirm as the leading latex exporter during the period of commitment while enjoy having income from the long CER (certificate emission reduction) lifespan, will also be having the environmental improvement from deforestation and land degradation as well as will provide huge volume of rubber wood as by product of the program when the commitment period ends for next 30 years on. Moreover, the lower stratrume crops such as food crops, vegetable, aromatic crops, and some silvo-medicines will also remain to contribute community income or at least for supporting subsistence poor consumption. The rubber wood production certainly will, further, bring multiplier effect on the country income through inducing wood processing industry including sawn wood, furniture, veneer, plywood, chemical pulp, fibre pulp, waste paper, paperboard etc. According to [13] Indonesia has been suffering from declining value of total wood products in the net international balance trade from USD 4,519(106) in 2005 to USD $1,136\left(10^{6}\right)$ in 2030. These values is equivalent to declining balance trade of wood products from $-1.0 \%$ to $-7.3 \%$ in 25 years. Beside, the defisite in balance trade will be larger when the $\mathrm{REDD}^{+}$implented intensively which wood stand must be retained as carbon stock in the field instead of cutting as logging. Based on this background, we intend to conduct this research.

\subsection{Research objective}

This research was aimed at revealing the impact of the variables of land's elevation dan slope exposition against solar beam radiation on rubber wood volume production under agroforestry system. 


\section{Material and method}

\subsection{Research location}

This research took place in December 2019 to January 2020 that carried out at Talang Manggo Village, Kasui District, Way Kanan Regency, Lampung-Indoensia, the focus was on the Mangga Mulyo HKm (Hutan Kemasyarakatan or social forestry) Group area that consists of 306 family heads with a total land area of 653 ha. This group is under the authority of the Bukit Punggur Forest Management Unit (BFMU) which according to [14] lies in parallel of $04^{\circ} 42^{\prime} 25.95^{\prime \prime}-04^{\circ} 57^{\prime} 09.72^{\prime \prime} \mathrm{S}$ and in meridian of $104^{\circ} 19^{\prime} 07.00 "$ " $-104^{\circ} 32^{\prime}$ 34.00 " E. controls the management area of around 45,075 ha consisting of 22796 ha as protected forest and the rest is production forest. Figure 1 presents a sketch of the orientation of the research site.

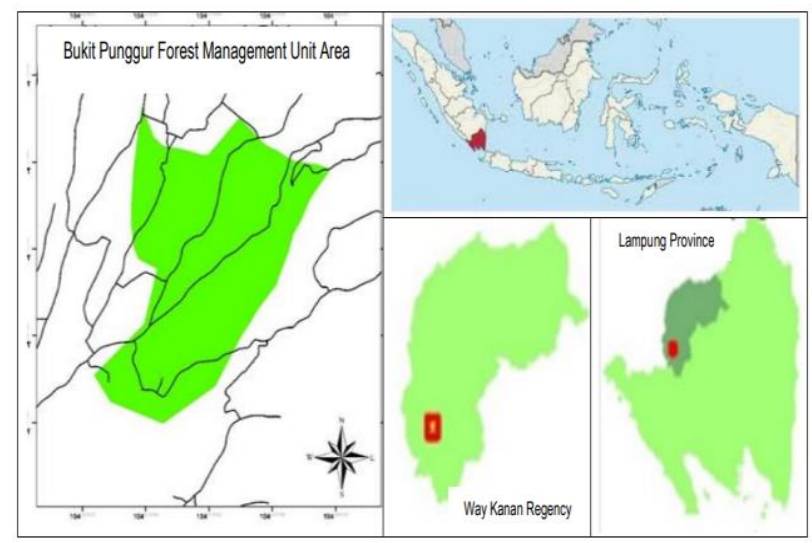

Fig. 1. Research site orientasion [17]

\subsection{Equipment}

The equipment used were consisted of thermo-hygrometer, altimeter, compass-clinometer, GPS and tape measurement meter (Figure 2).

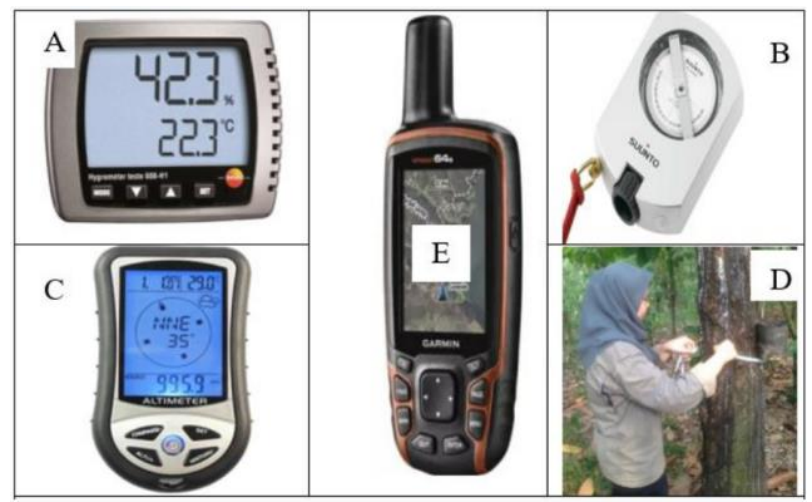

Fig. 2. Research equipments: A. Thermo_Hygrometer, B. Compas_Clinometer, C. Altimeter, D.Tape Measurement 


\subsection{Model approach}

The ordinary least square postulate model was employed to explain the rubber wood volume production [WOOD] as the respond variable of the land elevation [ELV] and slope exposition direction. The [ELV] measured using altimeter whereas the slope exposition against solar radiation direction using compass-clinometer. It is important to note that the slopes exposition directions are grouped into fours category. The first category is the slope exposition direction that prominent in accepting the morning solar beam radiation namely the east ward. According to [10] the east direction is the prominent face in accepting solar beam radiation in relation to photosynthesis for almost tropical crops as coffee robusta (Coffea canephora). So that we established the east ward as the reference for three other categories slope direction .

This reference, however, is not perfectly direction to $90^{\circ} .00^{\prime}$, but we prefer to the compass direction in between $337^{\circ} .30^{\prime}$ and $225^{\circ} .30^{\prime}$ follows the clock's needle. It because in the tropical region the solar beam radiation is still reach effectively to land with slope exposition direction wider than the northing or southing direction. Based on this reference we then established the tree others direction of slope exposition i.e. the southwest ward [SWST] = $202^{\circ} .30^{\prime}-247^{\circ} .30^{\prime}$; west ward $[\mathrm{WST}]=247^{\circ} .30^{\prime}-292^{\circ} .30^{\prime}$, and north west ward [NWST] $=$ $292^{\circ} .30^{\prime}-337^{0} .30^{\prime}$. Figure 3 is the illustration of division for fours slope exposition directions againts solar beam radiation.

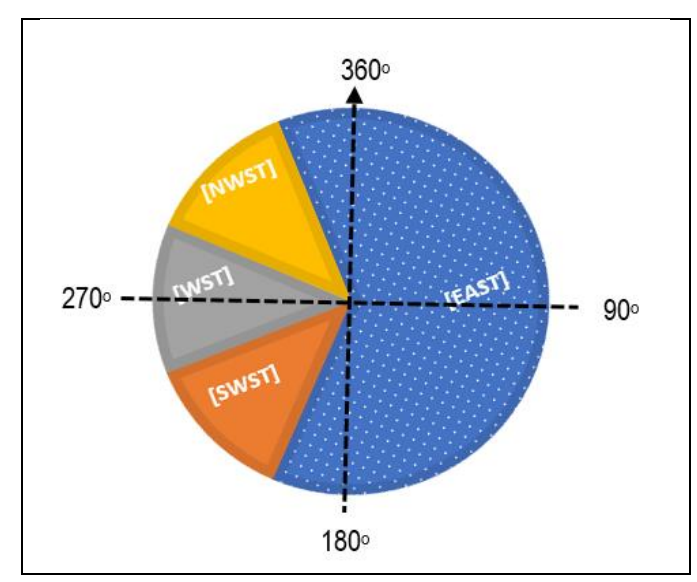

Fig. 3. Division of the slop exposition againts solar beam radiation into 4 categorics of direction

Additionally we further need to control the model error by incorporating the air humidity $[\mathrm{RH}]$ and air temperature [TEMP] variables. It was because we aware on one side that booth variable commonly has a significant effect on photosynthesis process that correspond to rubber wood production [WOOD], but on the other side we did not have booth the long data records, except for one moment during the survey. As for the model can be express in the following.

$$
\begin{gathered}
{[\mathrm{WOOD}]_{\mathrm{i}}=\alpha_{0}+\alpha_{1}[\mathrm{TEMP}]_{\mathrm{i}}+\alpha_{2}[\mathrm{RH}]_{\mathrm{i}}+\alpha_{3}[\mathrm{ELV}]_{\mathrm{i}}+\alpha_{4}[\mathrm{NWEST}]_{\mathrm{i}}} \\
+\alpha_{5}[\mathrm{WEST}]_{\mathrm{i}}+\alpha_{6}[\mathrm{SWEST}]_{\mathrm{i}}+\xi_{i}
\end{gathered}
$$




\subsection{Working hypothesis}

The working hypothesis was constructed as the following:

$H_{0}: \alpha_{1}=\alpha_{2}=\alpha_{3}=\alpha_{4}=\alpha_{5}=\alpha_{6}=0$; There was none of the six variable applied in the model affected significantly on rubber wood production.

$H_{1}: \alpha_{1} \neq \alpha_{2} \neq \alpha_{3} \neq \alpha_{4} \neq \alpha_{5} \neq \alpha_{6} \neq 0$; There would be at least one variable affect on the rubber wood production.

Where the $\alpha_{1}$ to $\alpha_{6}$ are the parameter model, $\xi_{i}$ is the error model, and $i$ are the sample numbers (where $i=1,2,3, \ldots, 75$ ). As for the other symbols, accompanied by predictor variables, data acquisition method, unit of measurements, and their data scoring are presented in Table 1.

Table 1. Predictor variables, symbol in model, unit of measurements, data scoring and their acquisition method

\begin{tabular}{|c|c|c|c|c|}
\hline $\begin{array}{l}\text { Predictor } \\
\text { Variables }\end{array}$ & $\begin{array}{l}\text { Symbol in } \\
\text { Model }\end{array}$ & $\begin{array}{c}\text { Measurem } \\
\text { ent Unit }\end{array}$ & Data Scoring & $\begin{array}{c}\text { Data } \\
\text { Acquisation }\end{array}$ \\
\hline $\begin{array}{l}\text { 1. Air } \\
\text { Temperature }\end{array}$ & [TEMP] & ${ }^{0} \mathrm{C}$ & as recorded & $\begin{array}{l}\text { Thermo- } \\
\text { Hygrometer }\end{array}$ \\
\hline 2. Air Humidity & {$[\mathrm{RH}]$} & $\%$ & as recorded & \\
\hline 3. Land Elevation & [ELV] & $\begin{array}{c}\text { a-100m } \\
\text { fold (ASL) }\end{array}$ & as recoded & Altimeter \\
\hline \multicolumn{5}{|c|}{ Slope Exposition $\left(337^{\circ} .30^{\prime} \text { to } 225^{\circ} .30^{\prime} \text { as the reference }\right)^{\mathfrak{f}}=0$} \\
\hline 4. South West & [S_WST] & Dummy & $\begin{array}{l}=1 \text { if } \\
\text { Southwest, =0 } \\
\text { if others }\end{array}$ & \\
\hline 5. West & [WEST] & Dummy & $\begin{array}{l}=1 \text { if West, } \\
=0 \text { if others }\end{array}$ & $\begin{array}{l}\text { Compass_Cl } \\
\text { inometer }\end{array}$ \\
\hline 6. North West & {$\left[\mathrm{N} \_W S T\right]$} & dummy & $\begin{array}{l}=1 \text { if } \\
\text { Northwest, } \\
=0 \text { if othres }\end{array}$ & \\
\hline
\end{tabular}

Note: $£$ follows the clock's needle

\subsection{Testing hypothesis}

In order to conduct on the hypothesis testing we need to collect data both for the respond and predictor variables, through a systematic survey. We drawn randomly 75 from 306 parcel of lands of land belong to HKm member as the sample. For every parcel of land we chose the best 10 of rubber crops then measure the diameter and hight of stem. Besides to measure data for the predictor variables as summarised in Table 1, and so did for scoring data and their unit of measurement. Testing hypothesis conducted by employing Minitab 16.

\section{Result and discussion}

Before discussing the model obtained, it is important to explore general information about the research area. For this purpose firstly need to reveals the descriptive statistic of data recorded. 


\subsection{Descriptive statistic}

For the sake of figuring general information about the data, in this section we need to depict the descriptive statistic as provided in the Table 2, include the average, maximum, minimum, and their standard error (SE). As for the frequency distribution of slope exposition against solar beam radiation is expressed in Figure 4.

The air temperature and air humidity during the survey (Table 2) was normally recorded in the tropical area. These variables are slightly different from [10] i.e $26.1(\mathrm{SE}=1.9)^{\circ} \mathrm{C}$ and $71.4(\mathrm{SE}=1.7) \%$ for the average of air temperature and air humidity respectively. The difference may be caused by the differences of range altitude both the area of research i.e from $349 \mathrm{~m}$ to $1,788 \mathrm{~m}$ ASL that lies in the parallel in between $05^{\circ} 48^{\prime}-05^{\circ} 22^{\prime} S$ The other possibility that made the differences was the time of conducting on of field research etc.

Table 2. Descriptive statistic of tree sample characteristic and land attribute of sampling area

\begin{tabular}{|c|c|c|c|c|c|c|}
\hline \multirow[b]{2}{*}{ Statistic } & \multicolumn{3}{|c|}{$\begin{array}{c}\text { Characteristic of Tree } \\
\text { Sample }\end{array}$} & \multicolumn{3}{|c|}{ Land Attributes } \\
\hline & $\begin{array}{l}\text { Hieght } \\
\text { of stem } \\
\text { (m) }\end{array}$ & $\begin{array}{c}\mathrm{DBH} \\
(\mathrm{m})\end{array}$ & $\begin{array}{c}\text { Wood } \\
\text { Volume } \\
\left(\mathrm{m}^{3}\right) / \text { tree } \\
\text { crop }\end{array}$ & $\begin{array}{c}\text { Elevatio } \\
\mathrm{n}(100 \mathrm{~m}) \\
\text { ASL }\end{array}$ & $\begin{array}{c}\text { Air } \\
\text { Temperatur } \\
\text { e }\left({ }^{0} \mathrm{C}\right)\end{array}$ & $\begin{array}{c}\text { Air } \\
\text { Humidit } \\
\text { y }(\%)\end{array}$ \\
\hline 1. Average & 7.45 & 0.156 & 0.49 & 7.07 & 30.50 & 23.56 \\
\hline $\begin{array}{l}\text { 2. Maximu } \\
\mathrm{m}\end{array}$ & 12.00 & 0.258 & 0.81 & 12.00 & 34.50 & 36.00 \\
\hline 3. Minimum & 5.00 & 0.051 & 0.16 & 5.25 & 26.50 & 16.00 \\
\hline 4. $\mathrm{SE}$ & 2.15 & 0.048 & 0.15 & 1.77 & 1.93 & 5.71 \\
\hline
\end{tabular}

Source: Field survey (2020). Note: $£$ calculated by the formula $=3.14\left(0.5^{*} \mathrm{DBH}\right)^{2 *}($ tree height $) \mathrm{m}^{3}$ $\mathrm{DBH}=$ diameter breast hieght

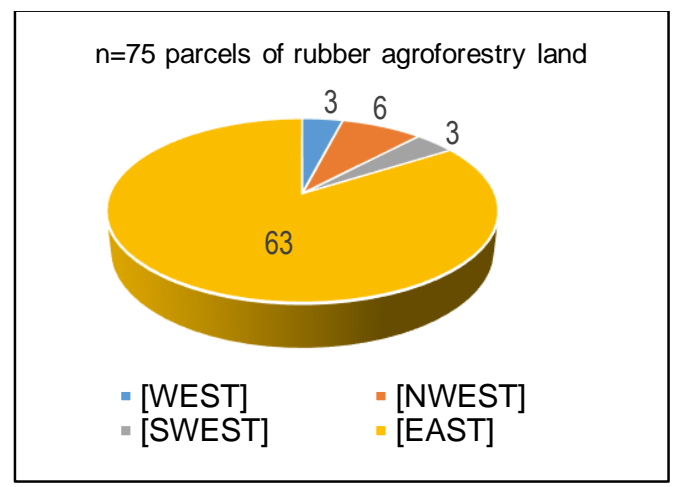

Fig 4. Data distribution frequency of 4 slopes exposition direction against solar radiation

As also can be examined in Table 2. the land elevations are located in between 7.07 to $12.00 \mathrm{hm}$ with the average $5.25 \mathrm{hm}$ above sea level (ASL). These distribution accompanied by respective statistic of their wood production i.e in between 0.49 to 0.81 and the average of $0.16 \mathrm{~m}^{3}$ per tree crop. In generic view, there is strong positively correlation between the two statistic. And so do to the air temperature and air humidity. These phenomena, however, 
have not been yet to claimed any causal relationship among these variables until we examined the regression $\mathrm{m}$

\subsection{The goodness fits of the model}

The results of the goodness fits test of model employed are provided in Table 3 as the following.

Table 3. The analysis of variance

\begin{tabular}{|l|c|c|c|c|c|}
\hline Source & DF & SS & MS & F & P \\
\hline Regression & 6 & 0.62719 & 0.10453 & 6.61 & $\mathbf{0 . 0 0 0 4}$ \\
\hline Residual error & 68 & 1.07469 & 0.10158 & & \\
\hline Total & 74 & 1.70188 & & & \\
\hline $\begin{array}{l}\text { Note: DF= Degrees of Freedom, SS=Sume Square Error, MS=Mean Square } \\
\text { Error }\end{array}$
\end{tabular}

Table 3 reflects that there is no proof to accept $H_{o}$. Then as the consequency we have to accept $H_{1}$, that there is at least one predictor variable that affect the [WOOD]. Besides the $P=0.0004$ achieved also tell us that the model is very good to predict the [WOOD]. With the indicator of $P=0.0004$ it tell us that in case the model to be utilized for predicting the [WOOD] at any other location of rubber agroforestry, so there will be 4 times miss out from 10,000 times of experiment. So that we can claim that the model is satisfied as the goodness of fits criterion (the $F$-test).

Having fulfilled the $F$ test, it is interesting in examining the 6 predictor variables which solely have a significant effect on [WOOD]. Table 4 depict the optimized parameters $\left(\alpha_{0}\right.$ to $\alpha_{6}$ ) of the 6 predictor variables applied in modelling. Based on these parameters achieved the significant role of every predictor variables on the [WOOD] can be justified.

Table 4. The optimized parameters of the 6 predictor variables applied in modeling

\begin{tabular}{|c|c|c|c|c|c|}
\hline Predictor Variable & Symbol & Coefficient $=\alpha_{n}$ & SE Coef. & $\mathbf{T}$ & $\mathbf{P}$ \\
\hline Constant & - & $-0.8908=\alpha_{0}$ & 0.47780 & -1.86 & 0.067 \\
\hline $\begin{array}{l}\text { Air Temperature } \\
\left({ }^{0} \mathrm{C}\right)\end{array}$ & [TEMP] & $0.0067=\alpha_{1}$ & 0.01297 & 2.83 & 0.006 \\
\hline Air Humidity (\%) & {$[\mathrm{RH}]$} & $0.0047=\alpha_{2}$ & 0.00441 & 1.06 & 0.295 \\
\hline $\begin{array}{l}\text { Land Elevation (a- } \\
100 \mathrm{~m} \text { fold }=\mathrm{hm} \text { ) }\end{array}$ & [ELV] & $0.0221=\alpha_{3}$ & 0.01048 & 2.10 & $\mathbf{0 . 0 3 9}$ \\
\hline \multicolumn{6}{|c|}{ Slope Exposition against solar beam radiation } \\
\hline -Northwest & [NWEST] & $0.0491=\alpha_{4}$ & 0.05917 & 0.83 & 0.409 \\
\hline -West & [WEST] & $-0.2153=\alpha_{5}$ & 0.07986 & -2.70 & 0.009 \\
\hline -Southwest & [SWEST] & $0.0386=\alpha_{6}$ & 0.07505 & 0.51 & 0.609 \\
\hline
\end{tabular}

\subsection{The role of air temperature and air humidity}

The role of air temperature, [TEMP], in affecting rubber wood production volume, [WOOD], is positively significant. This claim is proved by it $\alpha_{I}=0.00667 \mathrm{~m}^{3} /{ }^{\circ} \mathrm{C}$. It tells us that, if the others predictors variable are remain constant, there will be an increasement on [WOOD] for 
every $1{ }^{\circ} \mathrm{C}[\mathrm{TEMP}]$ rise up. This [WOOD] increasement is very significant in confident level of $99.04 \%$ as expressed by $\mathrm{P}=0.006$. It is important to note that this phenomenon can lead us to miss conclusion. We have to realize that data of [TEM] applied in the model was merely one moment during the field survey. The data standing are merely ex-post data and need to ex-ante data to verify the role of [TEMP] on the [WOOD].

As those expressed by $P=0.365$ (or $P>5 \%$ ), the air humidity [RH] does not any affect on the [WOOD]. But, this conclusion is also based on data temporary data collected during the survey. So that we also need an ex-ante data record in order to justify about this finding.

\subsection{The role of land elevation}

The role of land elevation, [ELV], has proved a positive impact on the [WOOD] as indicated by the parameter $\alpha_{3}=0.02205$. This parameter tells us that under the others variable retained remain constant, there will be an increasement [WOOD] by $0.02205 \mathrm{~m}^{3}$ per tree crop for every $1 \mathrm{hm}$ land elevation steps up across the landscape. This effect is significant as connoted by the $P=0.039$ (3.6\% or $P<5 \%$ ) or with the confident level more than $95 \%$. In line with this finding we need to recall the general theory of globe gravitation in connection with the photosyntetic behavior of $\mathrm{C} 3$ type as rubber crop [15] that in atmosphere space the partial pressure or saturation of every gas, including $\mathrm{CO}_{2}$, will reduce gradually following steps up to higher elevation across the landscape. This reducing $\mathrm{CO}_{2}$ concentration in the air will control directly to the photosynthesis rate of the $\mathrm{C} 3$ plants group as those of the rubber crop [15] and [16].

According to [17] the two indicators commonly used in the rate of photosynthesis are $\mathrm{Vc}_{\max }$ and $\mathrm{J}_{\max }$. The first indicator is to measure leaf maximum carboxylation rate and the second one is express the leaf's ability to transport electrons in the process of producing nicotinamide adenine dinucleotide phosphate or NADP, that is then used to control the carbon reactions. The $\mathrm{Vc}_{\max }$ determines the leaf's capacity in gaseous $\mathrm{CO}_{2}$ fixation from the air and converted into glucose within the dark reactions of the Calvin-Benson cycle. Besides, [18] conducted on an experiment using C3 plant to compare the effect of land elevation on photosynthesis rate with employed the two indicators and concluded that $\mathrm{Vc}_{\max }$ and $\mathrm{J}_{\max }$ were approximately $6.5 \%$ and $3.5 \%$ higher, respectively, in leaves from $\mathrm{C} 3$ plants that grown at the high land elevation than those grown at the low altitude, and the ratio of $J_{\max }$ to $V_{\text {cmax }}$ was $12.7 \%$ lower at the low altitude. They argued that in atmosphere space any partial gas pressure will gradually reduces following steps up across the landscape so does the $\mathrm{CO}_{2}$ pressure or concentration in the air. As a consequence, plants exposed to lower $\mathrm{CO}_{2}$ partial pressure and lower air temperature have a higher photosynthetic capacity at higher altitude or land elevation.

Additionally, the $\mathrm{Vc}_{\max }$ determines the leaf's capacity in carbon fixing and converted into glucose within the dark reactions of the Calvin-Benson cycle. Because the $\mathrm{V}_{\text {cmax }}$ is an indices of leaf maximum carboxylation rate [15], so the indices also correspond to the glucose formed, the first compound that produced in the photosynthesis process. The compound will, further, undergoes some biochemical processes that converts to more complex ones to build plants tissue including cellulose. As the main component of wood product, cellulose itself is a polysaccharide consisting of a linear chain of several hundred to many thousands of $\beta(1 \rightarrow 4)$ chemical bounding chain that links the d-glucose units [18]. At rest that why the [WOOD] more volume significantly for every move up to higher elevation as founded in this research. In contrast [19] reported that the latex production decrease following the land elevation steps up across the landscape. It seems any trade off between the wood synthesis and sap production especially in dividing photosynthesis result in rubber tree. Further research is in needing to reveals this interesting phenomenon. 


\subsection{The role of land slope exposition}

Among the 3 slope exposition against solar beam radiation only does the west ward direction, [WEST], that plays negative role on the [WOOD] as indicated by its parameter $\alpha_{5}=-0.21532$. This is meant that under scenario of the other variables are retained to remain constant, there will reduce the [WOOD] around $0.21532 \mathrm{~m}^{3}$ per tree crop for the lands that have slope exposition to west ward direction [WEST]. The effect is significant as connoted by $P=0.009$ $(0.9 \%$ or $P<1 \%)$. As for the lands have slope exposition both to [SWST] and [NWST] there are indifferent on [WOOD] from than that of the eastward direction [EAST].

Slope exposition against solar beam radiation of each parcel of land has effect on the photosynthesis rate as the function intensity of photon energy capturing by chlorophyll cells. The cells, therefore, are the main photon-harvesting component in leaves that closely linked to photosynthesis [15]. The photon energy intensity itself collides the stomata is much depend on the incidence angle of solar beam radiation and related to what time of sun light shining the leave. According to [20] the equinox point area is around the 12.00 o'clock, the time when the sun at the shortest distance to earth surface especially in the tropical region as the research area that located in between the parallel of $04^{\circ} 42^{\prime} 25,95^{\prime \prime} S$ and $04^{\circ} 57^{\prime} 09,72^{\prime \prime}$ $S$. The trees that planted on the field with slope land exposition of the [WEST], therefore, always receives the lowest photon energy for photosynthesis process. The effect is also founded in this research as expressed by the significant reducing [WOOD] around 0.21532 $(\mathrm{SE}=0,07986) \mathrm{m}^{3}$ per tree crop (Table 4) then that the [EAST].

\section{Concluding remarks}

The results suggest that the rubber wood production: (1) will increase significantly around $0.02205(\mathrm{SE}=0.01048) \mathrm{m}^{3}$ for every $100 \mathrm{~m}$ higher of land elevation, and (2) will decrease significantly around $-0.21532(\mathrm{SE}=0,07986) \mathrm{m}^{3}$ which land exposition face to westward than that of eastward direction.

We would like to offer acknowledgement to Mr. Muhamad Akhir, Head of Bukit Punggur Forest Management Unit, for providing technical assistance during the field survey.

\section{References}

1. Darojat, M. R and Sayurandi. Perspektif. 17,2:101- 116(2018). DOI: http://dx.doi.org/10.21082/psp.v17n2. [In Bahasa Indonesia].

2. Tangonyire, D.F. Malaysian Journal of Sustainable Agriculture. 3,2:46-55(2019). DOI : http://doi.org/10.26480/mjsa.02.2019.46.55.

3. Junaidi. Perspektif. 19,1:17-28(2020). DOI: http://dx.doi.org/10.21082/psp.v19n1. [In Bahasa Indonesia].

4. Anna, ICS., Ligia Regina LimaGouvêa2, Maria Alice Martins , Erivaldo José Scaloppi Junior, Rogério Soares de Freitas \& Paulo de SouzaGonçalves. Scientifict Report. 11:1081-191(2020). DOI: https://doi.org/10-1038/s41598-020-80110-w.

5. Hazir, M. H. M.H., R. A. Kadir, E. Gloor, and D. Galbraith. Effect of agroclimatic variability on landsuitability for cultivating rubber (Hevea brasiliensis) and growth performance assessment in thetropical rain forest climate of Peninsular Malaysia. $\begin{array}{lllll}\text { Climnate } & \text { Risk } & \text { Management. } & 27 & \text { (2020). }\end{array}$ https://doi.org/10.1016/j.crm.2019.100203. 
6. Nguyen, T.T., Truong Tat Do, Richard Harper, Trang Thanh Pham, Tran Vu Khanh Linh, Thai Son Le, Le Bao Thanh, and Nguyen Xuan Giap. Agriculture. 10,8:357370(2020). DOI: https://doi.org/10.3390/agriculture10080357

7. Junaidi. Jurnal Penelitian Karet. 37,2:73-184(2019). DOI : https://doi.org/10.22302/ppk.jpk.v37i2.653. [In Bahasa Indonesia].

8. Oktavia, F, C. T Stevanus, and F. Dessailly. Jurnal Penelitian Karet. 38,1:16(2020); DOI: https://doi.org/10.22302/ppk.jpk.v38i1.677 [In Bahasa Indonesia].

9. Bakri, S., I. Nurhaida, and A. Setiawan. Biodiversitas. 19,2:413-420(2018). DOI: https://10.13057/biodiv/d190208.

10. Nofyanza, S., M., V.Selviana, B. Dwisatrio, N. Liswanti, A. R. Tamara and M. Komalasari. Revisiting the REDD+ experience in Indonesia Lessons from national, subnational and local implementation. Info Brief \#314 (2020). DOI: https://10.17528/cifor/007880.

11. Pramudyanto, A. Jurnal Politik Internasional. 18,1: 76-93(2016). DOI: https://doi.org/10.7454/global.v18i1.119. [In Bahasa Indonesia].

12. Turner, J.A., J. Buongiorno, F. Maplesden, S. Zhu, S. Bates, R. Li. World Wood Industries Outloook 2005-2030 (2015). https://www.researchgate.net/publication.

13. Bukit Punggur Forest Management Unit. Rencana Pengelolaan Hutan Jangka Panjang Kesatuan Pengelolaan Hutan Produksi (KPHP) Model Bukit Punggur Kabupaten Way Kanan Provinsi Lampung Tahun 2015-2024. Way Kanan Regency, Blambangan Umpu_Lampung Province, Indonesia (2014). http://kph.menlhk.go.id/sinpasdok/public/RPHJP/1496031281RPHJP_KPHP_MO DEL_BUKIT PUNGGUR 2015-2024_pdf.pdf. [In Bahasa Indonesia].

14. Qian X., L. Liu, H.Croft, and J. Chen. C3 plants converge on a universal relationship between leaf maximum carboxylation rate and chlorophyll content. Biogeoscinece (2019). DOI: https://doi.org/10.5194/bg-2019-228.

15. Fan, Y., Z. Zhong, and X. Zhang. Agricultural and Forest Meteorology. 151,1:14811487(2011). DOI: https://10.1016/j.agrformet.2011.06.004.

16. Gupta, P. K., S. S. Raghunath, D.V. Prasanna, P. Venkat, V. Shree, C. Chithananthan, S. Choudhary, K. Surender and K. Geetha. An Update on Overview of Cellulose, Its Structure and Applications (2019). DOI: https://10.5772/intechopen.84727.

17. Zhafira, G., C. Wulandari, Rusita, and S Bakri. Pengaruh ketinggian tempat terhadap produksi getah karet Hutan Kemasyarakatan in Prosiding Seminar Nasional Biologi 4, 2019 Tema Pemanfaattan Biodiversitas dan Bioteknologi untuk Pelestarian Lingkungan, Universitas Islam Negeri Sunan Gunung Djati, Bandung 25 April 2019 : 181-185(2019).

18. Huang, L., L Deng, A. Li, R Gao, L Zhang, W Lei. Journal of Building Engineering. 32:1-13(2020). DOI: https://doi.org/10.1016/j.jobe.2020.101785. 